\title{
Ayushgraam - A Unique Approach in Public Health
}

\author{
Sudhir Joshi* \\ Dao Vadodara, Department of Ayush, Gujarat, India \\ *Corresponding author: Sudhir Joshi, Dao Vadodara, Department of Ayush, Gujarat, India
}

\begin{tabular}{|c|c|}
\hline ARTICLE INFO & ABSTRACT \\
\hline Received: 豐 April 21, 2021 & $\begin{array}{l}\text { Citation: Sudhir Joshi. Ayushgraam - A Unique Approach in Public Health. Biomed J Sci } \\
\& \text { Tech Res 38(3)-2021. BJSTR. MS.ID.006169. }\end{array}$ \\
\hline 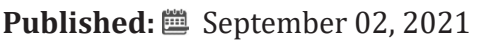 & \\
\hline
\end{tabular}

\section{Opinion}

"Ayushgraam" is a unique concept designed by the National Ayush Mission-Minsitry of AYUSH, Government of India. It's a proactive step for redefining public health. As per the guideline of the project, a village/ town with an average population of 5000 to 8000 or a town place with aggregate population of 5000 along with its peripheral villages is selected and multiple steps are taken for Promotion of general health as well as Prevention of the diseases. The principal aim of the project is to inculcate healthy habits as per Ayurvedic scriptures in the common people. This will help in promotion of a healthy society as well as prevent several diseases especially the Lifestyle disorders. We all know that today's era has seen huge upsurge in disease caused by faulty habits. This is the area where Ayurveda can help a lot. Timely modifications in dietary habits and daily routine can be game changer in long term. This is the core of this project, where stress would be laid on educating people. Some of the other salient features of the project are as below

1. Prepare health card of every family of selected town, wherein general details of every member would be noted.

2. Arrange medical camps on seasonal basis.

3. Conduct awareness camps about Ayurved and Yog.

4. Re- establish the ancient healthy recipes advocated in Ayurved.

5. Encourage people for developing kitchen garden so that small ailments could be cured by their help only.

6. Take special care of aged people from the diseases caused due to senescence and revive the concept of Rasayan chikitsa.
7. Take special care of pregnant woman and the developing child through measures given in Garbhini paricharya and thus do betterment of the mother as well as the progeny.

8. Distribute knowledge about the home remedies.

9. Impart knowledge of Ayurvedic principles to the children of school.

10. Utilize abandoned land, area in periphery of temple and other institutions for cultivating herbs and creating mass awareness about locally thriving herbs.

11. Impart knowledge of the lifestyle given in Ayurved i.e., Dincharya and Rutucharya to the Health workers, teachers and thus maximize the output.

12. Reinstate the ancient ways of exercise and popularize it.

As per the stipulated guidelines the District Ayurved Office Vadodara has started this project at Waghodiya town of Vadodara District. These are some of glimpses of the activities done at Ayushgram Waghodiya.

a. A mega camp was conducted on the day of inauguration.

b. Several standees were erected for dispersing knowledge about various principles of Ayurved

c. Exhibition depicting properties of common cereals, pulses, and vegetables as per Ayurvedic texts was done.

d. Specially designed miniature flag and key, displaying important principles of Ayurved were distributed to school children and eminent people. 
e. Survey of general health of around 1500 families of Waghodiya has been done with help of Health Card and efforts are being carried out to get some meaningful information from it.

f. Special medications are being given to the pregnant women and malnourished children of Waghodiya. Work in this area can give far reaching results. Encouraging results have been found in weight of malnourished children.

\section{ISSN: 2574-1241}

DOI: $10.26717 /$ BJSTR.2021.38.006169

Sudhir Joshi. Biomed J Sci \& Tech Res

(c) (P) This work is licensed under Creative

Submission Link: https://biomedres.us/submit-manuscript.php g. Preventive medicine that improve the immunity of the body were distributed extensively in the town during the COVID pandemic.

h. Other works like kitchen garden, useful publications for laymen etc are in pipeline.

i. The concept is really very useful in public health and implementation of the project at mass level may surely prove to be a game changer in long term.

$\begin{array}{ll}\text { BIOMEDICAL } & \text { Assets of Publishing with us } \\ \text { RESEARCHES } & \text { - Global archiving of articles } \\ & \text { - Immediate, unrestricted online access } \\ & \text { - Rigorous Peer Review Process } \\ & \text { - Authors Retain Copyrights }\end{array}$

